\title{
TINGKAT KEPUASAN MAHASISWA TERHADA KINERJA DOSEN MENGGUNAKAN FUZZY LOGIC (STUDI KASUS DI STTIND PADANG)
}

\author{
Indah Febriyani \\ Sistem Informasi, Sekolah Tinggi Teknologi Industri Padang \\ email: indahfebriyani@sttind.ac.id
}

\begin{abstract}
Abstrak: Dalam pendidikan tinggi, dosen memegang peranan yang penting dalam menghasilkan lulusan yang berkualitas dan terampil. Oleh karena itu, perlu dilakukan pengukuran untuk mengetahui kepuasan mahasiswa terhadap kinerja dosen yang ada di Kampus STTIND Padang. Untuk menentukan tingkat kepuasan mahasiswa dilakukan observasi dan penyebaran kuisioner kepada responden. Kuisioner sebagai alat untuk mengumpulkan data dan metode yang digunakan dalam mengukur tingkat kepuasan mahasiswa terhadap kinerja dosen adalah Fuzzy Logic metode Mamdani yang diimplementasikan melalui software Matlab 6.1. Hasilnya menunjukkan bahwa mahasiswa sudah cukup puas terhadap kinerja dosen di Prodi Teknik Pertambangan STTIND Padang. Dengan menggunakan Fuzzy Logic dapat menghasilkan informasi kinerja seorang dosen dalam mengajar dan dapat dijadikan sebagai evaluasi untuk meningkatkan kinerja dosen di masa yang akan datang.
\end{abstract}

Kata kunci: Kepuasan, Mahasiswa, Kinerja Dosen, Fuzzy Logic

\begin{abstract}
In higher education, lecturer holding an important role in producing graduates who are qualified and skilled. Therefore, it is necessary to know the student satisfaction measurement on performance of existing on-campus lecturer STTIND Padang. To determine the level of satisfaction of students performed observation and dissemination of the questionnaire to respondents. The questionnaire as a tool for collecting data and the methods used in measuring the level of satisfaction of students against the performance of lecturers is Mamdani Fuzzy Logic method that is implemented through software Matlab 6.1. The results show that students are already quite satisfied on performance lecturer in the course of Mining Engineering at STTIND Padang. By using Fuzzy Logic can generate performance information a lecturer in teaching and can serve as evaluation to improve performance in the future.
\end{abstract}

Keywords: Satisfaction, Students, The Performance Of Lecturers, Fuzzy Logic

\section{PENDAHULUAN}

Peningkatan mutu dari suatu perguruan tinggi dipengaruhi dari kualitas di perguruan tinggi tersebut. Sebagai salah satu perguruan tinggi swasta yang berada di lingkungan Kopertis Wilayah $X$, Sekolah Tinggi Teknologi Industri (STTIND) Padang mempunyai fungsi penting dalam masyarakat, terutama dalam mencerdaskan kehidupan bangsa. Dalam hal ini STTIND Padang perlu melakukan peningkatkan terhadap mutu dan kualitas pendidikan. Faktor yang sangat berpangaruh terhadap kualitas pendidikan adalah dosen. Peranan yang sangat penting dalam menghasilkan lulusan yang terampil dan berkualitas juga dipengang oleh seorang dosen.

Dalam upaya meningkatkan kualitas dosen dalam mengajar, STTIND Padang perlu melakukan evaluasi terhadap kinerja dosen, baik itu dosen tetap maupun dosen tidak tetap dari luar STTIND Padang. Evaluasi dilakukan untuk mengetahui tingkat kepuasan mahasiswa terhadap kinerja dosen di Kampus STTIND Padang khususnya dosen yang ada di Program Studi Teknik Pertambangan. 
Untuk mengetahui tingkat kepuasan mahasiswa terhadap kinerja dosen akan digunakan metode Fuzzy Logic yang diimplementasikan melalui software Matlab 6.1. Hal ini dilakukan dengan cara menyebarkan kuisioner kepada responden agar dapat memberikan penilaian yang lebih objektif.

Dalam penelitian ini, kuisioner digunakan sebagai alat pengumpulan data dan penilaian skor atribut - atribut pertanyaan pada kuisioner akan diolah menggunakan himpunan Fuzzy. Logika Fuzzy adalah cara memetakan ruang input ke dalam ruang output. Fuzzy dinyatakan dalam derajat keanggotaan dan derajat kebenaran. Logika Fuzzy yang menggunakan konsep kesamaran dari suatu nilai meniru cara berpikir manusia. Konsep logika Fuzzy membedakan keanggotaan himpunan dengan batasan yang samar, berbeda dengan himpunan klasik keanggotaan himpunan dibedakan menjadi dua yaitu anggota atau bukan anggota (Heri Prasetyo et al, 2014).

Kemampuan proses penalaran secara bahasa (linguistic reasoning) merupakan kelebihan dari teori logika Fuzzy. Sehingga persamaan matematik dari objek yang dikendalikan tidak diperlukan dalam perancangannya (Helfi Nasution, 2012). Logika Fuzzy menggunakan kata - kata yang jauh lebih dekat dengan intuisi manusia, sehingga manusia merasakan langsung nilai dari variabel kata - kata yang sudah umum dipakainya dalam kehidupan sehari - hari (Indrabayu et al, 2012).

\section{METODE PENELITIAN Lokasi Penelitian}

Sekolah Tinggi Teknologi Industri Padang beralamat di Jln Prof. Dr. Hamka No. 121 Tabing Padang. STTIND Padang terdiri dari 4 Prodi yaitu Teknik Industri, Teknik Pertambangan, Teknik Lingkungan serta Sistem Informasi dan sudah memiliki 2 gedung untuk perkuliahan.
Untuk mengetahui tingkat kepuasan mahasiswa terhadap kinerja dosen dilakukan penyebaran kuisioner kepada mahasiswa yang ada di Prodi Teknik Pertambangan.

\section{Analisa dan Perancangan}

Sebelum melakukan perancangan model sistem Fuzzy, untuk tahap awal akan ditentukan kriteria yang akan dipakai untuk mengetahui kepuasan mahasiswa terhadap kinerja dosen yang terdiri dari 5 macam dimensi kualitas yaitu Tangible, Reliability, Responsiveness, Assurance, dan Empathy.

Untuk mempermudah dalam memahami proses analisa dan perancangan yang dilakukan pada penelitian ini, maka dibuat diagram alir analisa dan perancangan seperti pada gambar berikut ini :

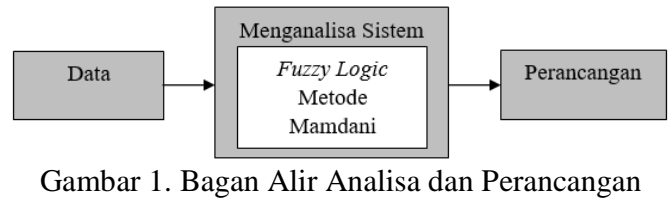

Analisa sistem dalam penelitian ini menggunakan Fuzzy Logic metode Mamdani, ada empat hal yang perlu diketahui dalam sistem Fuzzy yaitu variabel Fuzzy, himpunan Fuzzy, semesta pambicaraan, dan domain. Adapun tahapan - tahapan menganalisa sistem dalam penelitian ini adalah sebagai berikut :
1. Fuzzyfication dengan cara menentukan variabel Fuzzy, himpunan Fuzzy, semesta pambicaraan, dan domain.

2. Membentuk aturan (rule) logika Fuzzy yang dibutuhkan dengan melakukan Fuzzy Inference System (FIS).

3. Melakukan pengolahan data dengan Fuzzy.
a. Menghitung himpunan Fuzzy.
b. Menghitung Defuzzification Centroid.
c. Menghitung Defuzzy Weight Average.


Pada perancangan sistem ini terdapat lima variabel input yaitu : Tangible, Realibility, Responsiveness, Assurance, dan Empathy dengan satu variabel output yaitu Kepuasan Mahasiswa Terhadap Kinerja Dosen. Dengan cara klik edit dan klik add variabel input atau output, selanjutnya tentukan nama variabel input atau output yang digunakan pada bagian current variabel name seperti yang dapat dilihat pada gambar di bawah ini :

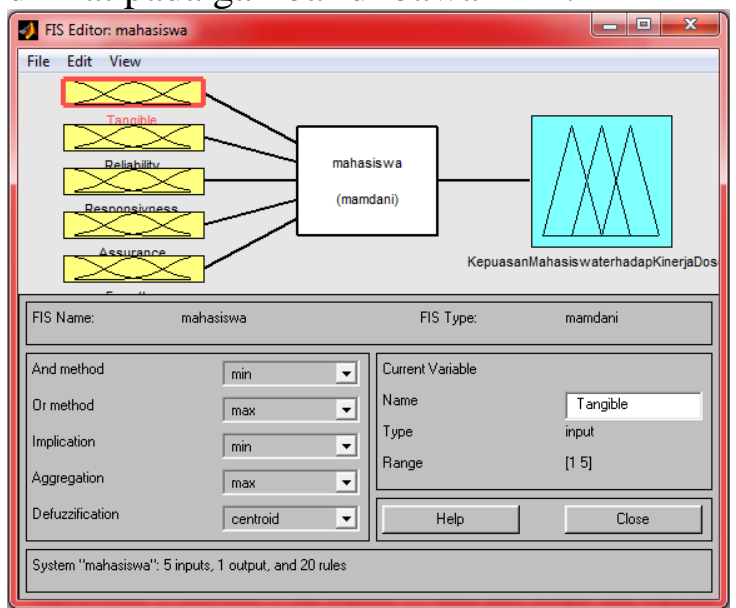

Gambar 2. Rancangan Input dan Output Pada FIS Editor

Dari variabel yang telah dimunculkan, dirancanglah domain himpunan Fuzzy seperti terlihat di bawah ini :

a. Himpunan Fuzzy Variabel Tangible Nilai variabel Tangible dibagi menjadi 3 kriteria yaitu :

Tabel 1. Himpunan Fuzzy Variabel Tangible

\begin{tabular}{|c|c|c|}
\hline $\begin{array}{c}\text { Semesta } \\
\text { pembicaraan }\end{array}$ & $\begin{array}{c}\text { Nama } \\
\text { himpunan } \\
\text { Fuzzy }\end{array}$ & Domain \\
\hline \multirow{3}{*}{$1-5$} & Kurang Puas & $1-3$ \\
\cline { 2 - 3 } & Puas & $2-4$ \\
\cline { 2 - 3 } & Sangat Puas & $3-5$ \\
\hline
\end{tabular}

Pada variabel input Tangible data yang dimiliki dapat dibagi menjadi 3 himpunan Fuzzy, yaitu : kurang puas, puas dan sangat puas. Himpunan Fuzzy kurang puas direpresentasikan dengan fungsi keanggotaan bahu kiri, fungsi keanggotaan untuk himpunan kurang puas dapat dilihat pada persamaan berikut :

$$
\mu \text { Kurang Puas }\left[X_{1}\right]=\left\{\begin{array}{cr}
\frac{3-x}{3-1} ; & 1 \leq x \leq 3 \\
0 & x \geq 3
\end{array}\right.
$$

Himpunan Fuzzy puas direpresentasikan dengan fungsi keanggotaan segitiga, fungsi keanggotaan untuk himpunan puas dapat dilihat pada persamaan berikut

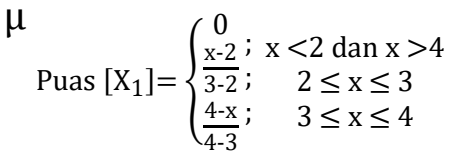

Himpunan Fuzzy sangat puas direpresentasikan dengan fungsi keanggotaan bahu kanan, fungsi keanggotaan untuk himpunan sangat puas dapat dilihat pada persamaan berikut :

$\mu$ Sangat Puas $\left[X_{1}\right]=\left\{\begin{array}{cr}0 ; & x \leq 3 \\ (x-3) /(5-3) & 3 \leq x \leq 5 \\ 1 ; & x \geq 5\end{array}\right.$

Bentuk representasinya terlihat pada gambar 3 sebagai berikut :

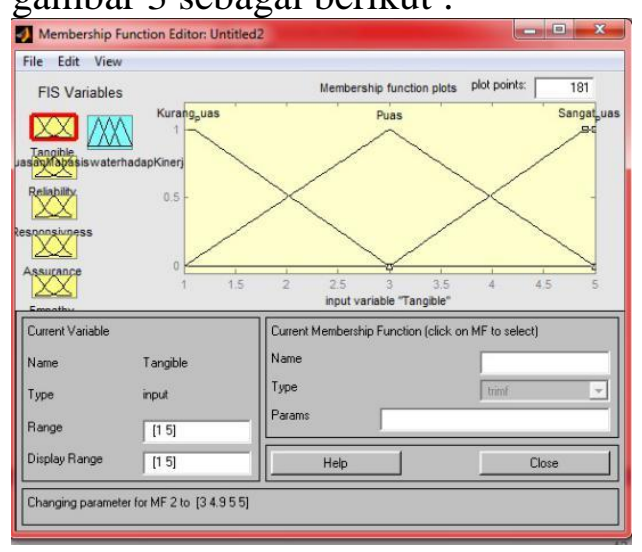

Gambar 3. Representasi Fungsi Derajat Keanggotaan Variabel Tangible

b. Himpunan Fuzzy Variabel Reliability Nilai variabel Reliability dibagi menjadi 3 kriteria yaitu :

Tabel 2. Himpunan Fuzzy Variabel Reliability

\begin{tabular}{|c|c|c|}
\hline $\begin{array}{c}\text { Semesta } \\
\text { pembicaraan }\end{array}$ & $\begin{array}{c}\text { Nama } \\
\text { himpunan } \\
\text { Fuzzy }\end{array}$ & Domain \\
\hline \multirow{3}{*}{$1-5$} & Kurang Puas & $1-3$ \\
\cline { 2 - 3 } & Puas & $2-4$ \\
\cline { 2 - 3 } & Sangat Puas & $3-5$ \\
\hline
\end{tabular}

Pada variabel input Reliability data yang dimiliki dapat dibagi menjadi 3 himpunan Fuzzy, yaitu : kurang puas, puas dan sangat puas. Himpunan Fuzzy kurang puas direpresentasikan dengan fungsi keanggotaan bahu kiri, fungsi keanggotaan untuk himpunan kurang 
puas dapat dilihat pada persamaan berikut :

$$
\mu \text { Kurang Puas }\left[X_{2}\right]=\left\{\begin{array}{cr}
\frac{3-x}{3-1} ; & 1 \leq x \leq 3 \\
0 & x \geq 3
\end{array}\right.
$$

Himpunan Fuzzy puas direpresentasikan dengan fungsi keanggotaan segitiga, fungsi keanggotaan untuk himpunan puas dapat dilihat pada persamaan berikut

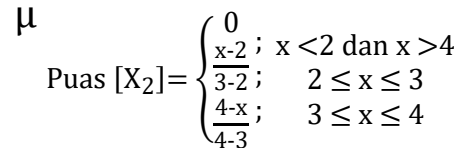

Himpunan Fuzzy sangat puas direpresentasikan dengan fungsi keanggotaan bahu kanan, fungsi keanggotaan untuk himpunan sangat puas dapat dilihat pada persamaan berikut :

$$
\mu \text { Sangat Puas }\left[X_{2}\right]=\left\{\begin{array}{cr}
0 ; & x \leq 3 \\
(x-3) /(5-3) & 3 \leq x \leq 5 \\
1 ; & x \geq 5
\end{array}\right.
$$

Bentuk representasinya terlihat pada gambar 4 sebagai berikut :

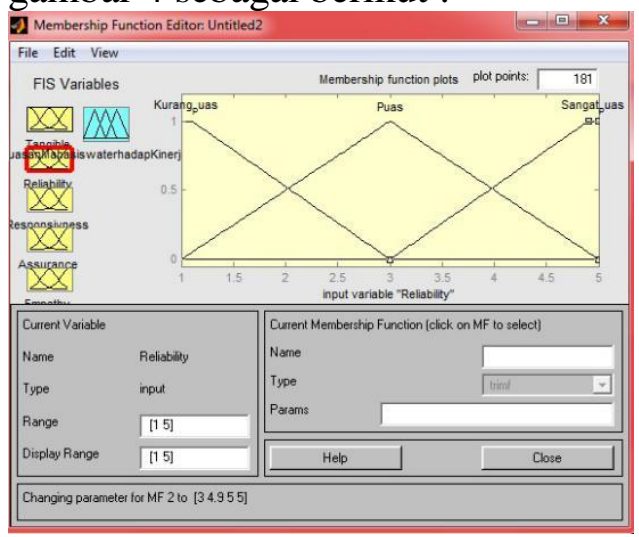

Gambar 4. Representasi Fungsi Derajat Keanggotaan Variabel Reliability

c. Himpunan Fuzzy Variabel Responsiveness

Nilai variabel Responsiveness dibagi menjadi 3 kriteria yaitu :

Tabel 3. Himpunan Fuzzy Variabel

\begin{tabular}{|c|c|c|}
\hline \multirow{2}{*}{$\begin{array}{c}\text { Semesta } \\
\text { pembicaraan }\end{array}$} & $\begin{array}{c}\text { Responsiveness } \\
\text { hama } \\
\text { himpunan } \\
\text { Fuzzy }\end{array}$ & Domain \\
\hline \multirow{3}{*}{$1-5$} & Kurang Puas & $1-3$ \\
\cline { 2 - 3 } & Puas & $2-4$ \\
\cline { 2 - 3 } & Sangat Puas & $3-5$ \\
\hline
\end{tabular}

Pada variabel input Responsiveness data yang dimiliki dapat dibagi menjadi 3 himpunan Fuzzy, yaitu : kurang puas, puas dan sangat puas. Himpunan Fuzzy kurang puas direpresentasikan dengan fungsi keanggotaan bahu kiri, fungsi keanggotaan untuk himpunan kurang puas dapat dilihat pada persamaan berikut :

$$
\mu \text { Kurang Puas }\left[X_{3}\right]=\left\{\begin{array}{cr}
\frac{3-x}{3-1} ; & 1 \leq x \leq 3 \\
0 & x \geq 3
\end{array}\right.
$$

Himpunan Fuzzy puas direpresentasikan dengan fungsi keanggotaan segitiga, fungsi keanggotaan untuk himpunan puas dapat dilihat pada persamaan berikut

$$
\mu \quad \text { Puas }\left[\mathrm{X}_{3}\right]= \begin{cases}0 & \\ \frac{\mathrm{x}-2}{3-2} ; & \mathrm{x}<2 \text { dan } \mathrm{x}>4 \\ \frac{4-\mathrm{x}}{4-3} ; & 3 \leq \mathrm{x} \leq 4 \\ & 3 \leq 4\end{cases}
$$

Himpunan Fuzzy sangat puas direpresentasikan dengan fungsi keanggotaan bahu kanan, fungsi keanggotaan untuk himpunan sangat puas dapat dilihat pada persamaan berikut :

$$
\mu \text { Sangat Puas }\left[\mathrm{X}_{3}\right]=\left\{\begin{array}{cr}
0 ; & \mathrm{x} \leq 3 \\
(\mathrm{x}-3) /(5-3) & 3 \leq \mathrm{x} \leq 5 \\
1 ; & \mathrm{x} \geq 5
\end{array}\right.
$$

Bentuk representasinya terlihat pada gambar 5 sebagai berikut :

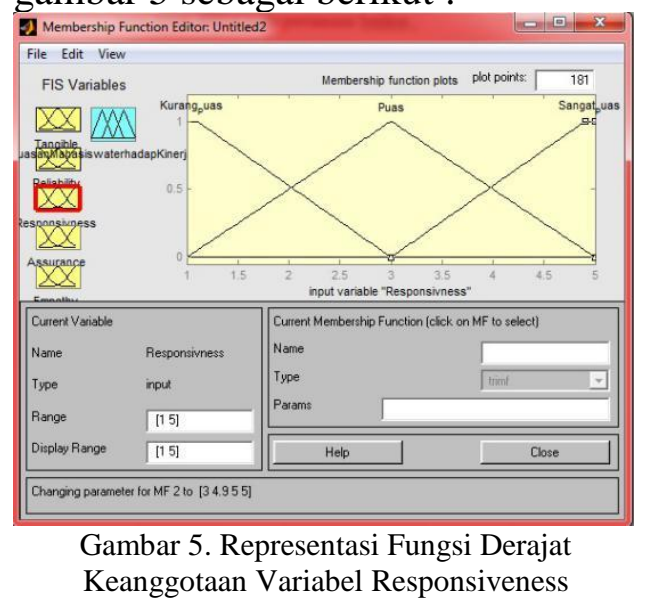

d. Himpunan Fuzzy Variabel Assurance Nilai variabel Assurance dibagi menjadi 3 kriteria yaitu :

Tabel 4. Himpunan Fuzzy Variabel Assurance

\begin{tabular}{|c|c|c|}
\hline $\begin{array}{c}\text { Semesta } \\
\text { pembicaraan }\end{array}$ & $\begin{array}{c}\text { Nama } \\
\text { himpunan } \\
\text { Fuzzy }\end{array}$ & Domain \\
\hline \multirow{2}{*}{$1-5$} & Kurang Puas & $1-3$ \\
\cline { 2 - 3 } & Puas & $2-4$ \\
\hline
\end{tabular}


\begin{tabular}{|l|l|l|}
\hline & Sangat Puas & $3-5$ \\
\hline Pada variabel input Assurance data
\end{tabular} yang dimiliki dapat dibagi menjadi 3 himpunan Fuzzy, yaitu : kurang puas, puas dan sangat puas. Himpunan Fuzzy kurang puas direpresentasikan dengan fungsi keanggotaan bahu kiri, fungsi keanggotaan untuk himpunan kurang puas dapat dilihat pada persamaan berikut :

$$
\mu \text { Kurang Puas }\left[\mathrm{X}_{4}\right]=\left\{\begin{array}{cr}
\frac{3-\mathrm{x}}{3-1} ; & 1 \leq \mathrm{x} \leq 3 \\
0 & \mathrm{x} \geq 3
\end{array}\right.
$$

Himpunan Fuzzy puas direpresentasikan dengan fungsi keanggotaan segitiga, fungsi keanggotaan untuk himpunan puas dapat dilihat pada persamaan berikut :

$$
\mu \text { Puas }\left[\mathrm{X}_{4}\right]= \begin{cases}0 & \\ \frac{\mathrm{x}-2}{3-2} ; & \mathrm{x}<2 \text { dan } \mathrm{x}>4 \\ \frac{4-\mathrm{x}}{4-3} ; & 3 \leq \mathrm{x} \leq 4 \\ \end{cases}
$$

Himpunan Fuzzy sangat puas direpresentasikan dengan fungsi keanggotaan bahu kanan, fungsi keanggotaan untuk himpunan sangat puas dapat dilihat pada persamaan berikut :

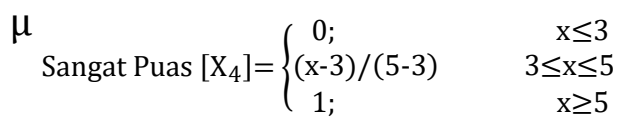

Bentuk representasinya terlihat pada gambar 6 sebagai berikut :

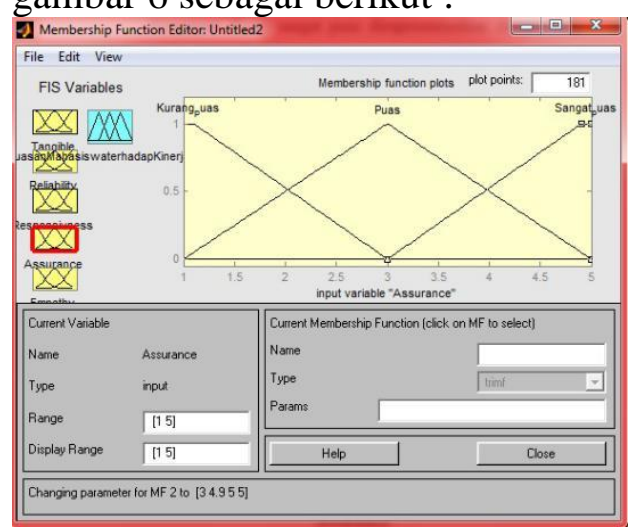

Gambar 6. Representasi Fungsi Derajat Keanggotaan Variabel Assurance

e. Himpunan Fuzzy Variabel Empathy Nilai variabel Empathy dibagi menjadi 3 kriteria yaitu :

Tabel 5. Himpunan Fuzzy Variabel Empathy

\begin{tabular}{|c|c|c|}
\hline $\begin{array}{c}\text { Semesta } \\
\text { pembicaraan }\end{array}$ & $\begin{array}{c}\text { Nama } \\
\text { himpunan } \\
\text { Fuzzy }\end{array}$ & Domain \\
\hline \multirow{3}{*}{$1-5$} & Kurang Puas & $1-3$ \\
\cline { 2 - 3 } & Puas & $2-4$ \\
\cline { 2 - 3 } & Sangat Puas & $3-5$ \\
\hline
\end{tabular}

Pada variabel input Empathy data yang dimiliki dapat dibagi menjadi 3 himpunan Fuzzy, yaitu : kurang puas, puas dan sangat puas. Himpunan Fuzzy kurang puas direpresentasikan dengan fungsi keanggotaan bahu kiri, fungsi keanggotaan untuk himpunan kurang puas dapat dilihat pada persamaan berikut :

$$
\mu \text { Kurang Puas }\left[\mathrm{X}_{5}\right]=\left\{\begin{array}{cr}
\frac{3-\mathrm{x}}{3-1} ; & 1 \leq \mathrm{x} \leq 3 \\
0 & \mathrm{x} \geq 3
\end{array}\right.
$$

Himpunan Fuzzy puas direpresentasikan dengan fungsi keanggotaan segitiga, fungsi keanggotaan untuk himpunan puas dapat dilihat pada persamaan berikut :

$$
\mu \quad \text { Puas }\left[X_{5}\right]= \begin{cases}0 & \\ \frac{x-2}{3-2} ; & x<2 \text { dan } x>4 \\ \frac{4-x}{4-3} ; & 3 \leq x \leq 4\end{cases}
$$

Himpunan Fuzzy sangat puas direpresentasikan dengan fungsi keanggotaan bahu kanan, fungsi keanggotaan untuk himpunan sangat puas dapat dilihat pada persamaan berikut :

$$
\mu \text { Sangat Puas }\left[X_{5}\right]=\left\{\begin{array}{cr}
0 ; & x \leq 3 \\
(x-3) /(5-3) & 3 \leq x \leq 5 \\
1 ; & x \geq 5
\end{array}\right.
$$

Bentuk representasinya terlihat pada gambar 7 sebagai berikut :

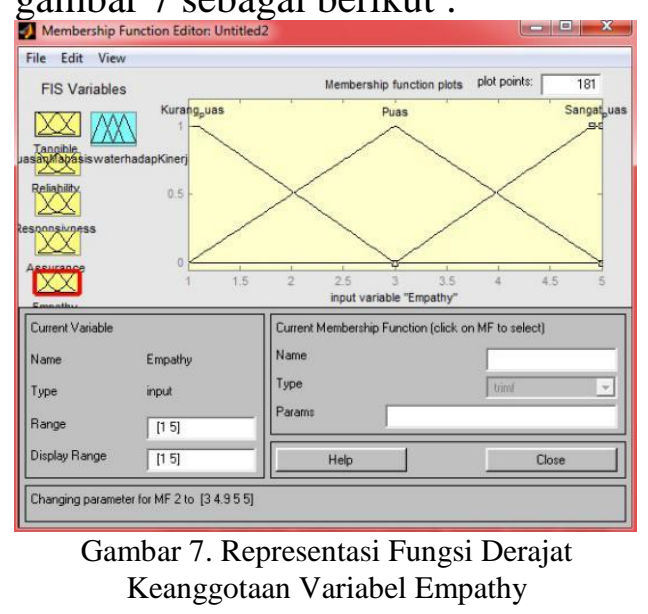


f. Himpunan Fuzzy Variabel Kepuasan Mahasiswa terhadap Kinerja Dosen Variabel Kepuasan Mahasiswa terhadap Kinerja Dosen adalah variabel output, yang merupakan tujuan akhir dari penelitian untuk menentukan tingkat kepuasan mahasiswa, nilai kepuasan mahasiswa terhadap kinerja dosen ditentukan dari kuisioner yang telah disebar dengan 5 dimensi kualitas yaitu : Tangible, Reliability, Responsiveness, Assurance, Empathy. Pada penelitian ini nilai variabel output Kepuasan Mahasiswa terhadap Kinerja Dosen dibagi menjadi 3 kriteria, yaitu Puas, Cukup Puas dan Tidak Puas. Fungsi derajat keanggotaan dari variabel Kepuasan Mahasiswa terhadap Kinerja Dosen dan nilai himpunannya didefinisikan sebagai berikut :

$$
\begin{array}{cc}
\mu_{\text {tp }}(\text { Tidak Puas })= & 1 \leq \mathrm{k} \leq 3 \\
& ; \mathrm{k}<3 \text { atau } \mathrm{k}>1 \\
& 2 \leq \mathrm{k} \leq 4 \\
\mu_{\mathrm{cp}}(\text { Cukup Puas })= & 0 ; \mathrm{k}<4 \text { atau } \mathrm{k}>2 \\
& 0 ; \mathrm{k}<5 \\
\mu_{\mathrm{p}}(\text { Puas })= & 3 \leq \mathrm{k} \leq 5
\end{array}
$$

Tabel 6. Himpunan Fuzzy Variabel Kepuasan

\begin{tabular}{|c|c|c|}
\hline \multicolumn{1}{|c}{ Mahasiswa Terhadap Kinerja Dosen } \\
$\begin{array}{c}\text { Semesta } \\
\text { pembicaraan }\end{array}$ & $\begin{array}{c}\text { Nama } \\
\text { himpunan } \\
\text { Fuzzy }\end{array}$ & Domain \\
\hline \multirow{3}{*}{$1-5$} & Kurang Puas & $1-3$ \\
\cline { 2 - 3 } & Puas & $2-4$ \\
\cline { 2 - 3 } & Sangat Puas & $3-5$ \\
\hline
\end{tabular}

Bentuk representasinya terlihat pada gambar 8 sebagai berikut :

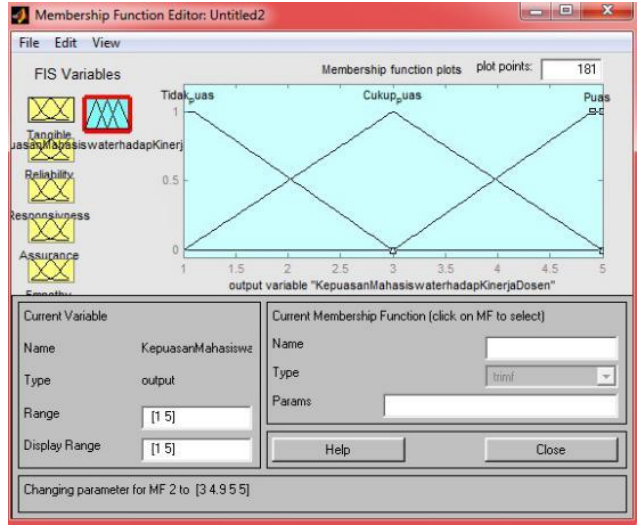

Gambar 8. Representasi Fungsi Derajat Keanggotaan Variabel Kepuasan Mahasiswa Terhadap Kinerja Dosen

Selanjutnya dilakukan perancangan terhadap aturan (rule) yang telah ditetapkan berdasarkan data yang telah didapat seperti gambar 3 :

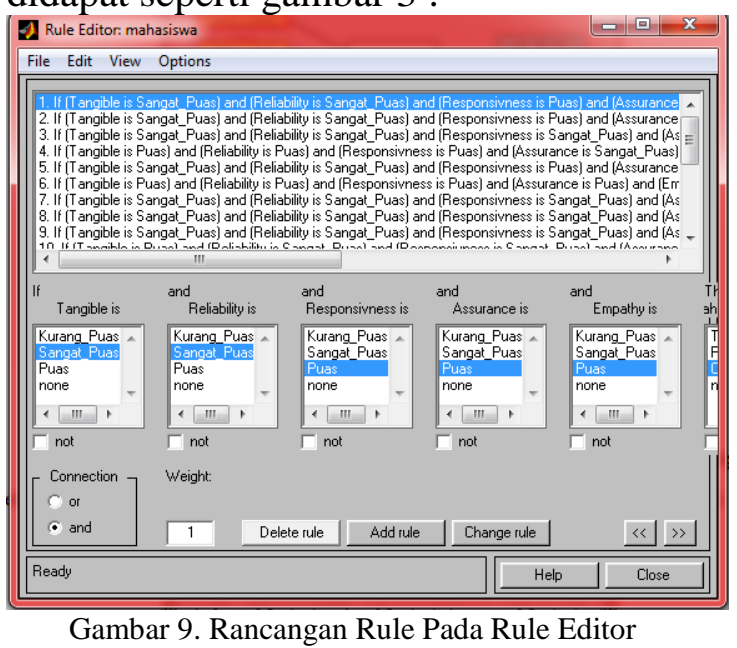

HASIL DAN PEMBAHASAN

Setelah dilakukan perancangan terhadap rule - rule yang ada, akan dilakukan penginputan data sampel responden 1 yaitu tangible 4,4, reliability 4,2 , responsiveness 3 , assurance 3 , dan empathy 3,3 maka akan didapat hasil kepuasan mahasiswa terhadap kinerja dosen sebesar 4. Hal ini dapat dilihat pada gambar 4 berikut :

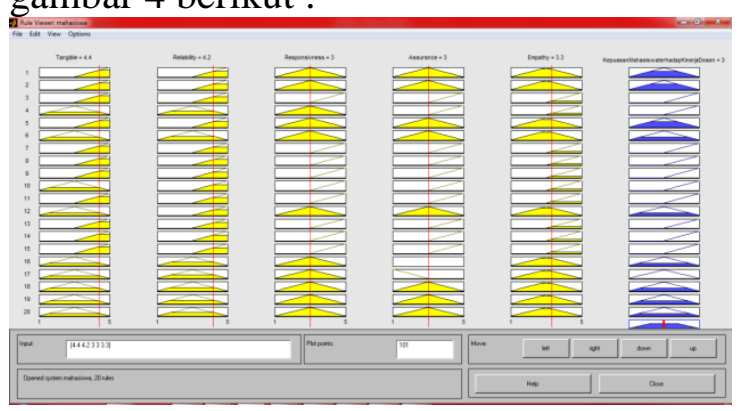


Gambar 10. Rule Viewer Responden 1

Hasil penghitungan data sampel di atas dapat dilihat pada tabel 1 , di mana tabel tersebut merepresentasikan perbandingan data hasil penghitungan manual Fuzzy dan aplikasi sistem inferensi sebagai berikut :

Tabel 7. Perbandingan Perhitungan Data Sampel

\begin{tabular}{|c|l|c|c|}
\hline No & \multicolumn{1}{|c|}{ Nama } & $\begin{array}{c}\text { Pengujian } \\
\text { Manual }\end{array}$ & $\begin{array}{c}\text { Perhitungan } \\
\text { Aplikasi }\end{array}$ \\
\hline 1 & Sampel Rule 5 & 3.2 & 3 \\
\hline 2 & Sampel Rule 6 & 4 & 3 \\
\hline 3 & Sampel Rule 12 & 4 & 3 \\
\hline
\end{tabular}

Pada Tabel 5 dapat dilihat perbandingan penghitungan antara hasil penilaian sistem yang digunakan dan hasil penghitungan Fuzzy secara manual. Dari hasil perhitungan Fuzzy secara manual maka kita dapat membandingkan dengan data asli. Dapat dilihat bahwa output yang didapat baik dari data asli ataupun dari perhitungan dengan Fuzzy manual masih berada dalam range yang sama.

\section{KESIMPULAN}

Bersadarkan penelitian yang telah dilakukan, maka dapat disimpulkan bahwa penerapan Fuzzy Logic metode Mamdani dapat mengetahui tingkat kepuasan mahasiswa terhadap kinerja dosen di Program Studi Teknik Pertambangan STTIND Padang, untuk mengukur tingkat kepuasan Mahasiswa terhadap kinerja dosen ada 5 kriteria yang digunakan yaitu tangible, reliability, responsiveness, assurance dan empathy.

Data input yang digunakan yaitu data kuisioner yang telah diisi oleh mahasiswa Program Studi Teknik Pertambangan di STTIND Padang kemudian dilakukan analisa terhadap data tersebut. Setelah dilakukan analisa terhadap data, hasilnya menunjukkan bahwa mahasiswa sudah cukup puas terhadap kinerja dosen di Prodi Teknik Pertambangan STTIND Padang.

\section{DAFTAR PUSTAKA}

Agustin, A.H., Gandhiadi, G.K., \& Oka, T.B. 2016. "Penerapan Metode Fuzzy
Sugeno untuk Menentukan Harga Jual Sepeda Motor Bekas." E-Jurnal Matematika. Vol - 5. 176 - 182.

Hesti, S., \& Iriananda, S. W. 2017. "Analisis Kepuasan Pelanggan Travel Menggunakan Metode Fuzzy Service Quality." Journal of Information Technology and Computer Science (JOINTECS). Vol - 2. 69-74.

Indrabayu, Harun, N., Pallu, M. S., Achmad, A., \& Febriyanti, F. 2012. "Prediksi Curah Hujan dengan Fuzzy Logic."Group Teknik Elektro. Vol 6.

Perangin-angin, R. \& Nababan, E. S. M. 2013. "Strategi Peningkatan Kualitas Pelayanan Kesehatan Menggunakan Integrasi Metode Fuzzy Servqual (Studi Kasus : RSU Vina Estetica Medan)." Saintia Matematika. Vol 1. 529-541.

Puspita, E. S. \& Yulianti, L. 2016. "Perancangan Sistem Peramalan Cuaca Berbasis Logika Fuzzy." Jurnal Media Infotama. Vol - 12. 1-10.

Puspitasari, Anggi. 2017. "Penggunaan Fuzzy Inference System (FIS) Metode Mamdani Untuk Menentukan Kinerja Pelayanan PDAM." Jurnal Teknik Komputer AMIK BSI. Vol - III. 5159.

Simanjuntak, M. \& Fauzi, A. 2017. "Penerapan Fuzzy Mamdani Pada Penilaian Kinerja Dosen (Studi Kasus STMIK Kaputama Binjai)." Jurnal ISD. Vol - 2. 143-149.

Tarigan, S. Y. B., Tobing, M. L., \& Situmorang, Z. 2017. "Mengukur Tingkat Kepuasan Mahasiswa Terhadap Kinerja Dosen Menggunakan Metode Fuzzy Mamdani." Semantika. 
Turnip, H., Situmorang, M., \& Siregar, R. 2014. "Analisis Kepuasan Mahasiswa terhadap Kualitas Pelayanan dengan Metode Fuzzy Service Quality (Studi Kasus di Departemen Matematika FMIPA USU)." Saintia Matematika. Vol - 2. 163 - 171.

Van FC, L. L., \& Lisnawita. 2017. " Analisis Kepuasan Pelanggan Terhadap Pelayanan Purnajual CV. Family Menggunakan Metode FuzzyLogic." Jurnal Inovtek Polbeng - Seri Informatika. Vol - 2. 64-67.

Wijayanto, D. D. K., Purnomo. H. D., \& Tampake. H. S. 2014. "Pemberian Rekomendasi Menu Makanan Menggunakan Logika Fuzzy.” 